\title{
Selection of Eggplant Cultivars and Combination with Graft Cultivation for Effective Biological Control of Vascular Wilt Diseases Using a Phenotypic Conversion Mutant of Ralstonia solanacearum
}

\author{
Hiroki Nakahara ${ }^{1 *}$, Akihiro Maehara², Taro Mori ${ }^{3}$ and Naotaka Matsuzoe ${ }^{2}$ \\ ${ }^{1}$ Arid Land Research Center, Tottori University, Tottori 680-0001, Japan \\ ${ }^{2}$ Graduate School of Environmental and Symbiotic Sciences, Prefectural University of Kumamoto, Kumamoto 862-8502, Japan \\ ${ }^{3}$ Faculty of Education, Shiga University, Otsu 520-0862, Japan
}

Ralstonia solanacearum causes bacterial wilt and undergoes spontaneous phenotypic conversion (PC) from its wild-type to an avirulent form. In previous studies, we reported that pre-inoculation of plants with PC mutants suppressed bacterial wilt and Verticillium wilt in eggplants. In addition, we previously revealed bacterial differences in the control effects in eggplant among PC mutants; 8107PC and 8103PC were selected as effective strains for controlling Verticillium wilt and bacterial wilt diseases, respectively. In this study, we investigated the biological control efficiencies of 8107PC inoculation among 19 eggplant cultivars, including 13 commercial cultivars and six rootstock cultivars, to select eggplant cultivars that stably prevent Verticillium wilt using PC mutants. Varietal differences in biological control were confirmed. Additionally, cultivars with a higher potential resistance to Verticillium wilt tended to be more suppressed by the PC mutant, suggesting that cultivar selection is important to achieve effective biocontrol. Furthermore, we found that the biocontrol with 8107PC against Verticillium wilt in grafted eggplant seedlings of Solanum melongena 'Senryo nigo' onto S. torvum 'Tonashimu' was the most effective rootstock cultivar against Verticillium wilt. The biocontrol was more effective than the non-grafted seedlings inoculated with the PC mutant and the grated seedlings not inoculated with the PC mutant. We also investigated biocontrol by the 8103PC inoculation against bacterial wilt using grafted seedlings ('Senryo nigo' as the scion) with 'Tonashimu' or S. melongena 'Daitaro' as rootstocks. Although 'Daitaro' had a low control effect against Verticillium wilt, the grafted seedlings showed a high control effect against bacterial wilt, regardless of the PC mutant inoculation. Conversely, seedlings grafted with 'Tonashimu' were vulnerable to bacterial wilt; however, inoculation with the PC mutant completely suppressed the disease. Therefore, this study demonstrated that bacterial wilt and Verticillium wilt could be effectively controlled by inoculation with PC mutants in seedlings grafted with 'Tonashimu'. The combination of grafting and PC mutant inoculation is expected to be effective for the combined control of Verticillium wilt and bacterial wilt diseases in eggplants.

Key Words: avirulent bacteria, bacterial wilt, rootstock, soil-borne diseases, Verticillium wilt.

\section{Introduction}

Eggplant (Solanum melongena L.) is a major global vegetable crop worldwide, with a production of approximately 55.2 million tons $(1,847,787 \mathrm{ha})$ and is an economically important vegetable crop in tropical and

Received; May 28, 2021. Accepted; June 24, 2021.

First Published Online in J-STAGE on August 31, 2021.

This study was supported in part by Grants-in-Aid for Scientific Research (No. 15K07299 and No. 19H03091) from the Japan Society for the Promotion of Science.

* Corresponding author (E-mail: nakaharah@tottori-u.ac.jp). subtropical countries (FAOSTAT, 2019). Eggplants are generally cultivated in open fields under hot and humid conditions and are susceptible to soil-borne vascular wilt diseases such as bacterial wilt, Verticillium wilt, and Fusarium wilt (Daunay, 2008).

Verticillium wilt, caused by the soil-borne fungal pathogen Verticillium dahliae, occurs in a wide range of hosts, including Solanaceae, Brassicaceae, and Cucurbitaceae crops (Pegg and Brady, 2002). This fungal pathogen infects the roots and invades the vascular tissues. The fungus forms conidia that are carried by the sap stream and migrate to the upper tissues of plants. 
After sporulation, the fungus enters the saprophytic stage during tissue necrosis or plant senescence (Fradin and Thomma, 2006). In eggplants with Verticillium wilt disease, the vascular tissue in the stem turns brown, and the symptoms of yellowing, wilting, and defoliation progress from the lower to the upper leaves (Hashimoto, 1989).

Bacterial wilt is caused by the soil-borne bacterium Ralstonia solanacearum. It occurs in tomato, eggplant, potato, and other crops and is widely distributed in tropical, subtropical, and warm temperate regions (Hayward, 1991). This bacterial pathogen infects the root and invades the vascular system, where it rapidly multiplies and produces extracellular polysaccharides (EPS) that lead to clogged vessels, wilting symptoms, and plant death (Kao et al., 1992; Saile et al., 1997).

To control vascular wilt diseases in eggplants, plants have been cultivated using soil fumigants and grafted onto resistant rootstocks (Mckeen and Mountain, 1967; Yamakawa, 1982; Duniway, 2002; Bletsos et al., 2003). However, completely controlling these diseases is difficult, because $R$. solanacearum can survive in moist soil, water microcosms, weeds, and plant residues for many years (Hayward, 1991); additionally, V. dahliae produces microsclerotia that can survive in soil and plant residues for several years (Pegg and Brady, 2002; Fradin and Thomma, 2006). Further, soil fumigants harm human health and the environment (Duniway, 2002). In the cultivation of eggplants by grafting onto resistant rootstocks, some wild species of Solaum plants such as S. integrifolium and S. torvum have been used as rootstock cultivars in Japan. However, no cultivars are completely resistant to Verticillium wilt and bacterial wilt (Yamakawa, 1982; Monma et al., 1997; Yoshida, 2007; Miki et al., 2011). A breakdown of resistance to bacterial wilt in rootstock cultivars has occurred because of new virulent strains of $R$. solanacearum and temperature increases in the culture conditions (Krausz and Thurston, 1975; Date et al., 1994). Additionally, the virulent strain of $R$. solanacearum has infected rootstocks and has been transferred to the scion, causing wilt symptoms in grafted seedlings (Nakaho et al., 1996). Therefore, new, environmentally friendly controls for vascular wilt diseases must be developed.

Biological control using beneficial microorganisms has attracted attention as an eco-friendly method for control, and endophytic bacterial genera (e.g., Pseudomonas, Bacillus, and Paenibacillus) are known to be effective biological control agents (BCAs) against vascular wilt diseases (Eljounaidi et al., 2016; O'Brien, 2017). In previous studies, we developed a method for the biological control of bacterial wilt in eggplants, tomatoes, and potatoes (Ogawa et al., 2011; Kuroki et al., 2016; Nakahara et al., 2016a, b) and Verticillium wilt in eggplants (Maehara et al., 2017; Nakahara et al., 2021b) using phenotypic conversion (PC) mutants of $R$. solanacearum. The wild-type strain of $R$. solanacearum spontaneously undergoes PC from fluidal colonies to non-fluidal colony morphology in broth culture, soil, plants, and water extracts of plants (Kelman and Hruschka, 1973; Mori et al., 2011, 2012; Nakahara et al., 2021a). PC mutants have several characteristics related to virulence factors, such as reduced EPS production, reduced endoglucanase and pectin methylesterase activities, and enhanced polygalacturonase and siderophore activities and motility; PC mutants can colonize the host tissue, but are either weakly virulent or avirulent (Kelman and Hruschka, 1973; Brumbley and Denny, 1990; Denny and Baek, 1991; Genin and Denny, 2012; Nakahara et al., 2021a). Previous studies showed that biological controls of bacterial wilt and Verticillium wilt differ depending on the selection of PC mutants (Nakahara et al., 2016a, b, 2021b). Moreover, varietal differences in the biological control of bacterial wilt are induced by PC mutants in eggplants, and the selection of eggplant cultivars is considered important for controlling bacterial wilt by PC mutants (Ogawa et al., 2011; Nakahara et al., 2016b). However, the existence of varietal differences in the biological control of Verticillium wilt in eggplant remains unclear; therefore, clarifying cultivars that demonstrate good biological control by PC mutants is necessary. In plants infected with the pathogen, defense-related enzymes are induced and are higher in cultivars with higher disease resistance (Vanitha and Umesha, 2008; Vanitha et al., 2009). Therefore, good control against the effects of bacterial wilt and Verticillium wilt diseases may be achieved by combining grafting cultivation and BCA inoculation, such as PC mutants; however, the control effects have not been verified.

In this study, we investigated varietal differences in the biological control of Verticillium wilt among 13 commercial cultivars and six rootstock cultivars and clarified the eggplant cultivars with good biological control by PC mutants to select those that stably prevent Verticillium wilt using PC mutants. Furthermore, to promote the use of grafting and $\mathrm{BCA}$ inoculation as a new disease control technique, we investigated the biological control of grafted seedlings inoculated with PC mutants against bacterial wilt and Verticillium wilt and determined the effectiveness of controlling vascular wilt diseases with the combined use of graft cultivation and PC mutant inoculation.

\section{Materials and Methods}

\section{Fungal strain}

The fungal pathogen Verticillium dahliae strain No. 5, which was isolated from eggplants, was provided by the Institute of Vegetable and Floriculture Science, National Agriculture and Food Research Organization (NARO), Japan. The fungal suspension was prepared at a concentration of $10^{6}$ conidia $\cdot \mathrm{mL}^{-1}$ according to the method described by Nakahara et al. (2021b). 


\section{Bacterial strains}

Ralstonia solanacearum strains 8103 (MAFF 730126 ) and 8107 (MAFF 107632), which are classified as race 1, biovar 4, phylotype I, and sequevar 15, were used in this study. The wild-type strain 8103 was used as a virulent strain of bacterial wilt. 8103PC was previously selected as an effective PC mutant for biological control of bacterial wilt in eggplants and tomatoes (Nakahara et al., 2016a, b) and was used as an effective PC mutant to control bacterial wilt in this study. 8107PC was previously selected from 27 PC mutants as an effective PC mutant for biological control of Verticillium wilt in eggplants (Nakahara et al., 2021b) and was used as a control for Verticillium wilt in this study. PC mutants were selected based on the shift from fluidal white to non-fluidal red colony morphology in a BGT medium ( $1 \%$ bacto peptone, $0.5 \%$ glucose, $0.1 \%$ yeast extract, $0.1 \%$ casamino acid, $1.5 \%$ agar, and $50 \mathrm{mg} \cdot \mathrm{L}^{-1}$ tetrazolium chloride [TZC]) after 14 days in a BG broth (BGT medium without $1.5 \%$ agar and $\left.50 \mathrm{mg} \cdot \mathrm{L}^{-1} \mathrm{TZC}\right)$ static culture. Bacterial suspensions were prepared according to the method described by Nakahara et al. (2016b). Colony-forming units (CFU) per milliliter of inoculum were prepared by dilution plating on a selective medium (BG medium supplemented with $50 \mathrm{mg} \cdot \mathrm{L}^{-1}$ cycloheximide, $50 \mathrm{mg} \cdot \mathrm{L}^{-1}$ polymyxin $\mathrm{B}, 25 \mathrm{mg} \cdot \mathrm{L}^{-1} \mathrm{TZC}, 10 \mathrm{mg} \cdot \mathrm{L}^{-1}$ chloramphenicol, and $5 \mathrm{mg} \cdot \mathrm{L}^{-1}$ crystal violet [Hara and Ono, 1983]).

\section{Plant materials}

Thirteen commercial eggplant (Solanum melongena) cultivars were used in this study, including 'Senryo nigo', 'Saitama ao daimaru', 'Chikuyo', 'Shoya onaga', 'Mizu nasu', 'Wase daimaru', 'Shitamachi bijin' (Takii \& Co., Ltd., Kyoto, Japan), 'Kurume naga', 'Sadowara', 'Aichi honnaga' (Asahi Noen Seed Co., Ltd., Aichi, Japan), 'Black Beauty' (Fuku Tane Co., Ltd., Fukui, Japan), 'Hitoshio' (Hokuetsu Noji Co., Ltd., Niigata, Japan), and 'Sendai naga' (Watanabe Seed Co., Ltd., Miyagi, Japan). Six rootstock cultivars (S. melongena 'Meet' and 'Daitaro', S. integrifolium 'Akanasu', S. integrifolium $\times$ S. melongena 'Taibyo-
VF', S. torvum 'Tonashimu', and 'Torvum vigar' [Takii]) were used in this study (Table 1). Seeds were surface-disinfected with $70 \%$ ethanol for $10 \mathrm{~s}$ and $1 \%$ sodium hypochlorite for $10 \mathrm{~min}$ and washed twice with SDW. The seeds were germinated and grown in vermiculite in a growth chamber maintained at $28^{\circ} \mathrm{C}$ for $12 \mathrm{~h}$ in light and at $22^{\circ} \mathrm{C}$ for $12 \mathrm{~h}$ in the dark. Seedlings were treated once or twice with liquid fertilizer ( $1 / 2$ strength OAT B solution; OAT Agrio Co., Ltd., Tokyo, Japan).

Varietal difference in the suppression of Verticillium wilt among eggplants by PC mutants

We used 8107PC, which is an effective PC mutant for biological control of Verticillium wilt in eggplants, from a selection of 27 PC mutants. Second-leaf stage seedlings of 19 eggplant cultivars were inoculated with a bacterial suspension of $8107 \mathrm{PC}\left(10^{8} \mathrm{CFU} \cdot \mathrm{mL}^{-1}\right)$. The seedlings were cut at approximately one third of their root length and then soaked in $20 \mathrm{~mL}$ of SDW or bacterial suspensions for $30 \mathrm{~min}$ as pre-inoculation. Inoculated seedlings were transplanted into 128-cell trays $\left(3 \times 3 \times 4 \mathrm{~cm}^{3}\right)$ filled with commercial soil contaminated with $V$.dahliae (ca. $10^{6}$ conidia $\cdot g^{-1}$ fresh weight [FW]) as a challenge inoculation. Inoculated plants were grown in a growth chamber $\left(25^{\circ} \mathrm{C}\right.$ for $12 \mathrm{~h}$ of light and $12 \mathrm{~h}$ of darkness). Plants were scored daily for disease symptoms on each leaf using an assessment key with four classes ( 0 , no symptoms; 1 , yellowing; 2, wilting; 3, defoliation). The disease severity of Verticillium wilt was calculated at 28 days after inoculation using the following formula: disease severity $(\%)$ $=\Sigma$ (disease symptoms of each leaf $) /(3 \times$ total number of leaves $) \times 100$. The biological control efficiency was calculated using the following formula: biological control efficiency $(\%)=[(\mathrm{A}-\mathrm{B}) / \mathrm{A}] \times 100$, where $\mathrm{A}$ and $\mathrm{B}$ are the percentages of disease severity in the control and PC treatments, respectively. Experiments were performed with 12 plants in each treatment and were conducted in duplicate or triplicate in successive trials. Suppression of Verticillium wilt in grafted eggplants
inoculated with a PC mutant

We used S. melongena 'Senryo nigo' as the scion and

Table 1. Low-temperature tolerance, plant vigor, and disease tolerance against soil-borne wilt diseases in eggplants of rootstock cultivars used in this study. ${ }^{2}$

\begin{tabular}{|c|c|c|c|c|c|c|}
\hline \multirow{2}{*}{ Classification } & \multirow{2}{*}{ Cultivar } & \multirow{2}{*}{$\begin{array}{c}\text { Low-temperature } \\
\text { tolerance }\end{array}$} & \multirow{2}{*}{ Plant vigor } & \multicolumn{3}{|c|}{ Disease tolerance } \\
\hline & & & & Bacterial wilt & Verticillium wilt & Fusarium wilt \\
\hline S. melongena & 'Meet' & Strong & Medium & Weak & Strong & Strong \\
\hline S. melongena & 'Daitaro’ & Medium & Strong & Strong & Weak & Strong \\
\hline S. integrifolium & 'Akanasu' & Strong & Strong & Weak & Weak & Strong \\
\hline S. integrifolium $\times S$. melongena & 'Taibyo-VF' & Very strong & Strong & Weak & Strong & Strong \\
\hline S. torvum & 'Tonashimu' & Medium & Very strong & Strong & Strong & Strong \\
\hline
\end{tabular}

z This table is based on the information about rootstock cultivars from Takii $<$ https://www.takii.co.jp/tsk/hinshu/daigi/ana.html $>$. 
S. torvum 'Tonashimu' as the rootstock in this experiment. Second-leaf stage seedlings were grafted and grown for 10 days to securely connect the scion and rootstock. The seedlings grafted onto S.torvum 'Tonashimu' and non-grafted seedlings of 'Senryo nigo' were removed from the trays; approximately one third of the root length was cut, and the roots were soaked in $20 \mathrm{~mL}$ of SDW or a bacterial suspension $\left(10^{8} \mathrm{CFU} \cdot \mathrm{mL}^{-1}\right)$ of $8107 \mathrm{PC}$ for $30 \mathrm{~min}$. Inoculated plants were transplanted into $10.5-\mathrm{cm}$ pots filled with commercial soil contaminated with V.dahliae (ca. $10^{6}$ conidia $\cdot \mathrm{g}^{-1} \mathrm{FW}$ ) and grown in a growth chamber $\left(25^{\circ} \mathrm{C}\right.$ for $12 \mathrm{~h}$ of light and $12 \mathrm{~h}$ of darkness). The disease severity of Verticillium wilt was calculated 28 days after inoculation. Experiments were performed with six plants in each treatment and repeated twice in successive trials.

Suppression of bacterial wilt in grafted eggplants inoculated with a PC mutant

We used S. melongena 'Senryo nigo' as the scion and S. torvum 'Tonashimu' and S. melongena 'Daitaro' as rootstocks in this experiment. The grafted seedlings were prepared as described previously. 8103PC was used as an effective PC mutant to control bacterial wilt in eggplants (Nakahara et al., 2016b). The seedlings grafted onto S. torvum 'Tonashimu' and S. melongena 'Daitaro' and the non-grafted seedlings of 'Senryo nigo' were removed from the trays. Then, approximately one third of the root length was cut, and the roots were soaked in $20 \mathrm{~mL}$ of SDW or a bacterial suspension $\left(10^{8} \mathrm{CFU} \cdot \mathrm{mL}^{-1}\right)$ of $8103 \mathrm{PC}$ for $30 \mathrm{~min}$. Inoculated plants were transplanted into $10.5-\mathrm{cm}$ pots filled with commercial soil contaminated with the virulent wildtype strain 8103 of $R$. solanacearum (ca. $10^{7} \mathrm{CFU} \cdot \mathrm{g}^{-1}$ $\mathrm{FW})$ and grown in a growth chamber $\left(30^{\circ} \mathrm{C}\right.$ for $12 \mathrm{~h}$ of light and $28^{\circ} \mathrm{C}$ for $12 \mathrm{~h}$ of darkness). The disease severity of bacterial wilt was calculated at 28 days after inoculation using the following formula: disease severity $(\%)=($ number of wilted leaves $) /($ total number of leaves) $\times 100$. Experiments were performed with six plants in each treatment and repeated twice in successive trials.

\section{Statistical analysis}

To ensure the homogeneity of the variances and symmetry of the distribution of each variable, data recorded as percentages were arcsine-transformed before performing a Student's $t$-test, one-way analysis of variance (ANOVA) following the Tukey-Kramer test, and Pearson's correlation coefficient, which was used to analyze the relationship between the disease severity of Verticillium wilt in the control and the PC treatments among 19 eggplant cultivars. Statistical analysis was performed using SPSS Statistics version 25 (IBM Corp., Armonk, NY, USA).

\section{Results and Discussion}

Varietal differences in the suppression of Verticillium wilt among commercial eggplant cultivars by $P C$ mutants

In a previous study, $8107 \mathrm{PC}$ was selected as the most effective PC mutant for the biological control of Verticillium wilt in eggplants from 27 PC mutants (Nakahara et al., 2021b). In this study, we tested the varietal differences among 19 eggplants (13 commercial cultivars and six rootstock cultivars) in the biological control of Verticillium wilt using 8107PC. The potential resistance and biological control differed between the eggplant cultivars (Tables 2 and 3).

In the commercial cultivars of $S$. melongena, the biological control efficiencies of Verticillium wilt varied from 3.2 to 67.1 (Table 2). Disease severity was significantly suppressed by $8107 \mathrm{PC}$ inoculation in 10 cultivars, except 'Chikuyo', 'Sendai naga', and 'Shitamachi bijin'. In 'Mizu nasu', the disease severity was the highest in the control (88.2\%) and the lowest in the PC mutant inoculation $(29.0 \%)$, resulting in the highest biological control efficiency of all the cultivars. In 'Shitamachi bijin', the disease severity was low $(33.1 \%)$ in the PC mutant inoculation, but lower in the control (52.4\%) than in any other cultivar, resulting in a lack of significant suppression. Varietal differences exist in the biological control of bacterial wilt induced by PC mutants in commercial eggplant cultivars (Ogawa et al., 2011; Nakahara et al., 2016b). In 'Kurume naga',

Table 2. Varietal differences in suppression of Verticillium wilt among 13 commercial eggplant cultivars (Solanum melongena) by $8107 \mathrm{PC}$ inoculation.

\begin{tabular}{|c|c|c|c|}
\hline \multirow{2}{*}{ Cultivar } & \multicolumn{2}{|c|}{ Disease severity $(\%)^{z}$} & \multirow{2}{*}{$\begin{array}{c}\text { Biological } \\
\text { control } \\
\text { efficiency }(\%)^{\mathrm{y}}\end{array}$} \\
\hline & Control & Treatment & \\
\hline 'Mizu nasu’ & $88.2 \pm 2.5$ & $29.0 \pm 6.1 *$ & 67.1 \\
\hline 'Hitoshio' & $86.0 \pm 3.2$ & $36.2 \pm 6.1 *$ & 57.9 \\
\hline 'Aichi honnaga' & $82.8 \pm 3.0$ & $36.6 \pm 7.9 *$ & 55.8 \\
\hline 'Black Beauty' & $76.1 \pm 3.9$ & $35.7 \pm 5.5^{*}$ & 53.1 \\
\hline 'Wase daimaru' & $71.7 \pm 2.3$ & $36.9 \pm 4.8^{*}$ & 48.5 \\
\hline 'Kurume naga' & $57.5 \pm 3.4$ & $29.7 \pm 5.2 *$ & 48.4 \\
\hline 'Senryo nigo' & $63.9 \pm 2.9$ & $33.2 \pm 4.3^{*}$ & 48.0 \\
\hline 'Sadowara' & $65.6 \pm 4.4$ & $36.7 \pm 7.1 *$ & 44.0 \\
\hline 'Shoya onaga' & $60.6 \pm 2.9$ & $37.1 \pm 4.8^{*}$ & 38.7 \\
\hline 'Shitamachi bijin' & $52.4 \pm 3.5$ & $33.1 \pm 9.0$ & 36.8 \\
\hline 'Saitama ao daimaru' & $87.1 \pm 2.6$ & $66.2 \pm 5.1^{*}$ & 24.0 \\
\hline 'Sendai naga' & $74.0 \pm 3.8$ & $59.7 \pm 8.0$ & 19.4 \\
\hline 'Chikuyo' & $72.6 \pm 3.3$ & $70.2 \pm 4.8$ & 3.2 \\
\hline
\end{tabular}

${ }^{z}$ Data show mean \pm standard error of 12 plants in each treatment done in duplicate or triplicate in successive trials $(\mathrm{n}=24-36)$ at 28 days after inoculation. Asterisks indicate significant differences $(P$ $<0.05$ ) between the control and 8107PC treatments in each cultivar according to the Student's $t$-test; the percentage values were obtained through arcsine transformation.

${ }^{y}$ Data show the average of two or three replicates. 
Table 3. Varietal difference in suppression of Verticillium wilt among six rootstock cultivars in eggplants by $8107 \mathrm{PC}$ inoculation.

\begin{tabular}{|c|c|c|c|c|}
\hline \multirow{2}{*}{ Classification } & \multirow{2}{*}{ Cultivar } & \multicolumn{2}{|c|}{ Disease severity $(\%)^{z}$} & \multirow{2}{*}{$\begin{array}{c}\text { Biological control } \\
\text { efficiency }(\%)^{\mathrm{y}}\end{array}$} \\
\hline & & Control & Treatment & \\
\hline S. torvum & 'Tonashimu' & $18.7 \pm 3.6$ & $3.5 \pm 2.0 *$ & 81.5 \\
\hline S. integrifolium & 'Akanasu’ & $29.2 \pm 4.9$ & $11.6 \pm 4.1 *$ & 60.4 \\
\hline S. melongena & 'Meet' & $32.3 \pm 3.7$ & $13.8 \pm 2.5^{*}$ & 57.4 \\
\hline S. torvum & 'Torvum vigar' & $32.3 \pm 3.9$ & $15.6 \pm 3.2 *$ & 51.7 \\
\hline S. integrifolium $\times S$. melongena & 'Taibyo-VF' & $39.5 \pm 4.8$ & $27.6 \pm 4.7$ & 30.1 \\
\hline
\end{tabular}

z Data show mean \pm standard error of 12 plants in each treatment that was repeated twice in successive trials $(\mathrm{n}=24)$ at 28 days after inoculation. Asterisks indicate significant differences $(P<0.05)$ between the control and 8107PC treatments in each cultivar according to the Student's $t$-test; the percentage values were obtained through arcsine transformation.

y Data show the average of two replicates.

'Senryo nigo', 'Sadowara', and 'Shoya onaga'-cultivars with strong control effects against bacterial wilt by PC mutants (Ogawa et al., 2011; Nakahara et al., 2016b) - the biological control of Verticillium wilt was also relatively high (Table 2). Conversely, in 'Saitama ao daimaru', 'Sendai naga', and 'Chikuyo'_cultivars with low biological control of bacterial wilt (Ogawa et al., 2011; Nakahara et al., 2016b) - the biological control of Verticillium wilt was also low. In 'Mizu nasu', 'Hitoshio', and 'Black Beauty'_cultivars with low biological control of bacterial wilt (Ogawa et al., 2011; Nakahara et al., 2016b) - the biological control against Verticillium wilt was relatively high in this study. Therefore, selecting cultivars with strong effects is important to obtain stable biological control of Verticillium wilt and bacterial wilt by PC mutants.

Varietal difference in suppression of Verticillium wilt among rootstock cultivars of eggplant by PC mutants

Grafting cultivation has become widespread as a control for soil-borne vascular wilt diseases; however, rootstock cultivars have partial resistance to Verticillium wilt, causing disease in grafted plants (Yamakawa, 1982; Bletsos et al., 2003). Varietal differences in resistance to Verticillium wilt exist among rootstock cultivars; the resistance in S.melongena 'Daitaro' and S. integrifolium 'Akanasu' is weak, whereas S. melongena 'Meet', S. integrifolium $\times S$. melongena 'Taibyo-VF', S. torvum 'Tonashimu', and 'Torvum vigar' have strong resistance (Table 1; Yamakawa, 1982; Monma et al., 1997; Yoshida, 2007; Miki et al., 2011). In this study, no rootstock cultivars completely controlled Verticillium wilt; the potential resistance in the rootstock cultivars was consistent with Table 1, except for S. integrifolium 'Akanasu', which showed relatively strong resistance (Table 3). When 8107PC was inoculated in the rootstock cultivars, resistance to Verticillium wilt tended to increase. In S.torvum 'Tonashimu', the potential resistance was the highest in this study; the resistance was further enhanced by inoculation with $8107 \mathrm{PC}$ and biological control efficiency was the highest at $81.5 \%$.

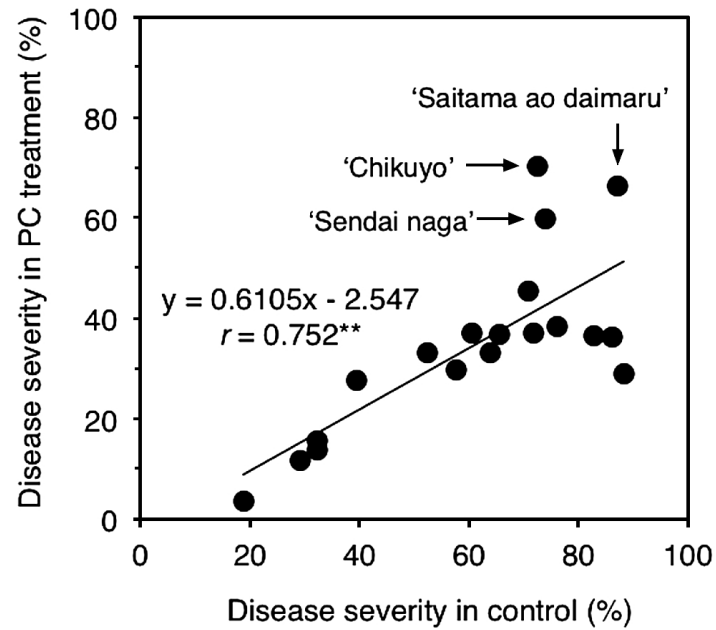

Fig. 1. Relationship between the disease severities of Verticillium wilt in the control and PC treatments among 19 eggplant cultivars. The disease severities show the average of 12 plants in each cultivar in duplicate or triplicate in successive trials. Correlation $(r)$ with $P<0.01$ is indicated as a double asterisk by the Pearson's correlation coefficient; the percentage values were obtained through arcsine transformation.

Relationship between the disease severity of Verticillium wilt among eggplant cultivars in the control and $P C$ treatments

In the control of bacterial wilt by PC mutants, eggplant cultivars with higher potential resistance tend to have better control effects by PC mutants (Ogawa et al., 2011; Nakahara et al., 2016b). In this study, a significant positive correlation $(r=0.752, P<0.01)$ was observed between the disease severity of Verticillium wilt in the control and PC treatments among 19 eggplant cultivars (Fig. 1), suggesting that suppression by PC treatment tended to be higher in cultivars with higher resistance to Verticillium wilt. Disease defencerelated enzymes such as phenylalanine ammonia-lyase, polyphenol oxidase, peroxidase, and lipoxygenase are at higher levels in cultivars with higher resistance to disease (Vanitha and Umesha, 2008; Vanitha et al., 2009). Furthermore, the expression of these defenserelated enzymes is also induced by pre-inoculation with 
Pseudomonas fluorescens, which is known as a BCA against several diseases and is stronger against bacterial wilt in resistant cultivars than in susceptible cultivars (Vanitha and Umesha, 2011). In our previous study, expression of pathogenesis-related (PR) protein genes (e.g., basic $\beta-1,3$-glucanase $(P R-2 b)$, basic chitinase $(P R-3 b)$, thaumatin-like protein $(P R-5)$, and proteinase inhibitor II $(P R-6))$ were induced in tomatoes inoculated with PC mutants (Nakahara et al., 2016a). The PR-2b and PR-3b proteins are involved in the degradation of chitin and glucan, which are cell wall constituents of fungi; the PR-5 protein has antifungal activity (van Loon et al., 1994; Tjamos et al., 2005; Bu et al., 2014). In this study, a similar mechanism may have been involved in the suppression of Verticillium wilt by PC mutants, and higher resistance is likely induced by inoculation with the PC mutant into cultivars with high potential resistance. Future studies need to clarify varietal differences in the expression of disease defense-related genes by PC mutant treatments.

Suppression of Verticillium wilt and bacterial wilt in grafted eggplants inoculated with PC mutants

Solanum torvum is strongly resistant to bacterial wilt and Verticillium wilt (Monma et al., 1997; Yoshida, 2007; Miki et al., 2011). In seedlings grafted with S. melongena 'Senryo nigo' onto S. torvum 'Tonashimu' and those inoculated with $8107 \mathrm{PC}$, Verticillium wilt was significantly suppressed compared to that in the nongrafted seedlings and those inoculated with 8107PC (Table 4). The biological control by the PC mutant increased in grafted seedlings, suggesting that inoculation of grafted seedlings with PC mutants enhanced the resistance of plants against Verticillium wilt.

Ralstonia solanacearum has been classified into five bacterial groups (I-V) based on differences in virulence to four Solanum species (S. melongena, S. mammosum, S. integrifolium, and S. torvum) in Japan. Additionally, bacterial group IV isolates have the strongest pathogenicity and affect all four Solanum species (Ozaki and Kimura, 1992). The resistance to bacterial wilt in S. torvum is destroyed by bacterial group IV isolates and high temperatures (Date et al., 1994). In a pre- vious study, 8103PC was selected as an effective PC mutant for biological control of bacterial wilt in eggplant cultivars (Nakahara et al., 2016b). In this study, we tested biological control of bacterial wilt caused by the virulent wild-type strain 8103 , which is classified in bacterial group IV of R. solanacearum, in the grafted seedlings of S. melongena 'Senryo nigo' grafted onto 'Tonashimu' or 'Daitaro' of rootstock cultivars with 8103PC inoculation. The resistance to bacterial wilt in 'Tonashimu' was destroyed by the virulent wild-type strain 8103. In the seedlings grafted onto 'Tonashimu', bacterial wilt was not controlled without PC mutant inoculation; conversely, the disease was completely suppressed by the PC mutant inoculation (Table 5). Seedlings grafted with 'Daitaro' effectively controlled bacterial wilt without PC mutant inoculation (Table 5). However, 'Daitaro' was not suitable to control Verticillium wilt because it had the highest disease severity among rootstock cultivars in both the control and PC mutant treatments (Table 3). Therefore, the combination of grafting with 'Tonashimu' and inoculation of PC mutants most effectively controlled bacterial wilt and Verticillium wilt diseases in eggplants.

Two mechanisms have been considered for the induction of resistance in grafted seedlings. The first is that rootstocks induce high resistance and suppresses the transfer of pathogens into the scion (Guan et al., 2012). The second is the transfer of signaling substances and defense-related substances from rootstocks to scions. Signaling substances (e.g. salicylic acid and jasmonic acid) from the rootstock are transmitted to the scion, and PR proteins are expressed in the scion $(\mathrm{Li}$ et al., 2002; Verberne et al., 2003; Heil and Ton, 2008). The PR proteins expressed in the rootstock are transferred to the scion (Bortolotti et al., 2005). In this study, grafted seedlings inoculated with PC mutants may have enhanced rootstock functions.

\section{Conclusions}

In this study, varietal differences in the biological control of Verticillium wilt among 13 commercial cultivars and six rootstock cultivars by inoculation with a PC mutant were confirmed. Verticillium wilt was sup-

Table 4. Biological control of Verticillium wilt in grafted eggplants by 8107PC inoculation.

\begin{tabular}{lccc}
\hline \hline \multirow{2}{*}{ Treatment ${ }^{\mathrm{z}}$} & \multicolumn{2}{c}{ Disease severity (\%) } & $\begin{array}{c}\text { Biological control } \\
\text { efficiency }(\%)^{\mathrm{x}}\end{array}$ \\
\cline { 2 - 3 } & Control & Treatment & 27.7 \\
Non-grafted & $79.9 \pm 4.7 \mathrm{a}$ & $57.8 \pm 7.3 \mathrm{~b}$ & 58.7 \\
Grafted onto 'Tonashimu' & $20.1 \pm 7.7 \mathrm{c}$ & $8.3 \pm 4.0 \mathrm{c}$ & 5 \\
\hline
\end{tabular}

\footnotetext{
${ }^{z}$ Non-grafted seedlings of $S$. melongena 'Senryo nigo', a commercial cultivar, and the grafted seedlings of 'Senryo nigo' grafted onto $S$. torvum 'Tonashimu', a rootstock cultivar, were used. In the PC treatment, the seedlings were soaked in water or bacterial suspensions $\left(10^{8} \mathrm{CFU} \cdot \mathrm{mL}^{-1}\right)$ of $8107 \mathrm{PC}$ for $30 \mathrm{~min}$, and then transplanted into pots filled with commercial soil contaminated with $V$. dahliae (ca. $10^{6} \mathrm{conidia}^{-1} \mathrm{~g}^{-1} \mathrm{FW}$ ).

${ }^{y}$ Data show the mean \pm standard error of six plants in each treatment that was repeated twice in successive trials $(\mathrm{n}=12)$ at 28 days after inoculation. Different letters indicate significant differences $(P<0.05)$ according to one-way ANOVA following the Tukey-Kramer test; the percentage values were obtained through arcsine transformation.

${ }^{x}$ Data show the average of two replicates.
} 
Table 5. Biological control of bacterial wilt in grafted eggplants by $8103 \mathrm{PC}$ inoculation.

\begin{tabular}{|c|c|c|c|}
\hline \multirow{2}{*}{ Treatment $^{\mathrm{z}}$} & \multicolumn{2}{|c|}{ Disease severity $(\%)^{\mathrm{y}}$} & \multirow{2}{*}{$\begin{array}{c}\text { Biological control } \\
\text { efficiency }(\%)^{\mathrm{x}}\end{array}$} \\
\hline & Control & Treatment & \\
\hline Non-grafted & $66.7 \pm 14.2 \mathrm{a}$ & $13.9 \pm 9.6 \mathrm{~b}$ & 79.2 \\
\hline Grafted onto 'Tonashimu' & $70.8 \pm 12.7 \mathrm{a}$ & $0.0 \pm 0.0 \mathrm{c}$ & 100.0 \\
\hline Grafted onto 'Daitaro' & $8.3 \pm 8.3 b c$ & $0.0 \pm 0.0 \mathrm{c}$ & 100.0 \\
\hline
\end{tabular}

${ }^{z}$ Non-grafted seedlings of $S$. melongena 'Senryo nigo', a commercial-cultivar, and the grafted seedlings of 'Senryo nigo' grafted onto $S$. torvum 'Tonashimu' or S. melongena 'Daitaro', rootstock cultivars, were used. In the PC treatment, the seedlings were soaked in water or bacterial suspensions $\left(10^{8} \mathrm{CFU} \cdot \mathrm{mL}^{-1}\right)$ of $8103 \mathrm{PC}$ for $30 \mathrm{~min}$, and then transplanted into pots filled with commercial soil contaminated with the pathogenic strain 8103 of $R$. solanacearum (ca. $10^{7} \mathrm{CFU} \cdot \mathrm{g}^{-1} \mathrm{FW}$ ).

${ }^{y}$ Data show mean \pm standard error of six plants in each treatment that was repeated twice in successive trials $(\mathrm{n}=12)$ at 28 days after inoculation. Different letters indicate significant differences $(P<0.05)$ according to one-way ANOVA following the Tukey-Kramer test; the percentage values were obtained through arcsine transformation.

${ }^{x}$ Data show the average of two replicates.

pressed by inoculation with the PC mutant in some eggplant cultivars, and the cultivars with a higher potential resistance to Verticillium wilt tended to be more suppressed by the PC mutant. In rootstock cultivars, S. torvum 'Tonashimu' and S. melongena 'Daitaro' effectively controlled Verticillium wilt and bacterial wilt, respectively. Selecting effective cultivars is important to achieve stable biological control of Verticillium wilt and bacterial wilt by PC mutants. Furthermore, we proved that bacterial wilt and Verticillium wilt can be effectively controlled by inoculation with PC mutants in seedlings grafted with 'Tonashimu'. The combination of grafting and inoculation with PC mutants is expected to be an effective technique for the combined control of vascular wilt diseases in eggplants.

\section{Acknowledgements}

We are grateful to Dr. Takeo Saito of the Institute of Vegetable and Floriculture Science, NARO, for providing the Verticillium dahliae strain. H. N. thanks the Research Fellowships for Young Scientists from the Japan Society for the Promotion of Science.

\section{Literature Cited}

Bletsos, F., C. Thanassoulopoulos and D. Roupakias. 2003. Effect of grafting on growth, yield, and Verticillium wilt of eggplant. HortScience 38: 183-186.

Bortolotti, C., I. Murillo, P. Fontanet, M. Coca and B. San Segundo. 2005. Long-distance transport of the maize pathogenesis-related PRms protein through the phloem in transgenic tobacco plants. Plant Science 168: 813-821.

Brumbley, S. M. and T. P. Denny. 1990. Cloning of wild-type Pseudomonas solanacearum phcA, agene that when mutated alters expression of multiple traits contribute to virulence. J. Bacteriol. 172: 5677-5685.

Bu, B., D. Qiu, H. Zeng, L. Guo, J. Yuan and X. Yang. 2014. A fungal protein elicitor PevD1 induces Verticillium wilt resistance in cotton. Plant Cell Rep. 33: 461-470.

Date, H., H. Nasu and M. Hatamoto. 1994. Breakdown of resistance of eggplant rootstock (Solanum torvum Swartz) to bacterial wilt by high ambient temperature. Ann. Phytopathol. Soc. Jpn. 60: 483-486.

Daunay, M. C. 2008. Eggplant. p. 163-220. In: J. Prohens and
F. Nuez (eds.). Vegetables II. Handbook of Plant Breeding: vol. 2. Springer New York, N.Y.

Denny, T. P. and S. R. Baek. 1991. Genetic evidence that extracellular polysaccharide is a virulence factor of Pseudomonas solanacearum. Mol. Plant-Microbe. Interact. 4: 198-206.

Duniway, J. M. 2002. Status of chemical alternatives to methyl bromide for pre-plant fumigation of soil. Phytopathology 92: 1337-1343.

Eljounaidi, K., S. K. Lee and H. Bae. 2016. Bacterial endophytes as potential biocontrol agents of vascular wilt diseasesReview and future prospects. Biological Control 103: 62-68.

Food and Agriculture Organization of United Nations (FAO), Statistics Division. 2019. <http://www.fao.org/faostat/en/ data/QC $>$ (Accessed: March 16, 2021).

Fradin, E. F. and B. P. Thomma. 2006. Physiology and molecular aspects of Verticillium wilt diseases caused by $V$. dahliae and V. albo-atrum. Mol. Plant Pathol. 7: 71-86.

Genin, S. and T. P. Denny. 2012. Pathogenomics of the Ralstonia solanacearum species complex. Annu. Rev. Phytopathol. 50: 67-89.

Guan, W., X. Zhao, R. Hassell and J. Thies. 2012. Defense mechanisms involved in disease resistance of grafted vegetables. HortScience 47: 164-170.

Hara, H. and K. Ono. 1983. Ecological studies on the bacterial wilt of tobacco, caused by Pseudomonas solanacearum E.F. Smith, I. A selective medium for isolation and detection of Pseudomonas solanacearum. Bull. Okayama Tob. Exp. Stn. 42: $127-138$.

Hashimoto, K. 1989. Transmission cycle of Verticillium wilt of eggplant and method of detection of causal fungus, Verticillium dahliae from soil. Soil Microorganisms 33: 3545 (In Japanese).

Hayward, A. C. 1991. Biology and epidemiology of bacterial wilt caused by Pseudomonas solanacearum. Annu. Rev. Phytopathol. 29: 65-87.

Heil, M. and J. Ton. 2008. Long-distance signalling in plant defence. Trends in Plant Sci. 13: 264-272.

Kao, C. C., E. Barlow and L. Sequeria. 1992. Extracellular polysaccharide is required for wild-type virulence of Pseudomonas solanacearum. J. Bacteriol. 174: 1068-1071.

Kelman, A. and J. Hruschka. 1973. The role of motility and aerotaxis in the selective increase of avirulent bacteria in still broth cultures of Pseudomonas solanacearum. J. Gen. Microbiol. 76: 177-188.

Krausz, J. P. and H. D. Thurston. 1975. Breakdown of resistance to Pseudomonas solanacearum in tomato. Phytopathology 65: $1272-1274$. 
Kuroki, T., T. Mori, A. Komatsu, H. Nakahara, H. Matsusaki and N. Matsuzoe. 2016. Suppression of bacterial wilt in potatoes by non-pathogenic Ralstonia solanacearum using bud pieces and plant grown from bud pieces. Hort. Res. (Japan) 15: 207-212 (In Japanese with English abstract).

Li, L., C. Li, G. I. Lee and G. A. Howe. 2002. Distinct roles for jasmonate synthesis and action in the systemic wound response of tomato. Proc. Natl. Acad. Sci. USA 99: 64166421.

Maehara, A., H. Nakahara, T. Mori and N. Matsuzoe. 2017. Biological control of Verticillium wilt in eggplant using a Ralstonia solanacearum non-pathogenic mutant strain. Hort. Res. (Japan) 16: 497-502 (In Japanese with English abstract).

Mckeen, C. D. and W. B. Mountain. 1967. Soil fumigation for control of Verticillium wilt of eggplant. Can. J. Plant Sci. 47: $1-10$.

Miki, S., T. Urushibara and S. Shibata. 2011. Varietal difference in resistance to Verticillium wilt of eggplant in rootstock. Annu. Rep. Kanto-Tosan Plant Protec. Soc. 58: 35-37 (In Japanese).

Monma, S., S. Akazawa, K. Shimosaka, Y. Sakata and H. Matsunaga. 1997. 'Daitaro', a bacterial wilt- and Fusarium wilt-resistant hybrid eggplant for rootstock. Bulletin of the National Research Institute of Vegetables, Ornamental Plants and Tea 12: 73-83 (In Japanese with English abstract).

Mori, T., T. Fujiyoshi, T. Inada, H. Matsusaki, K. Ogawa and N. Matsuzoe. 2011. Phenotypic conversion of Ralstonia solanacearum in susceptible and resistant Solanum plants. Environ. Control Biol. 49: 165-176.

Mori, T., T. Inada, H. Matsusaki, K. Ogawa and N. Matsuzoe. 2012. Phenotype conversion of Ralstonia solanacearum in water extract of Solanum toxicarium. J. Plant Pathol. 94: $535-542$.

Nakahara, H., K. Mori, T. Mori and N. Matsuzoe. 2021a. Induction of spontaneous phenotype conversion in Ralstonia solanacearum by addition of iron compounds in liquid medium. J. Microbiol. Meth. 186: 106233. DOI: 10.1016/ j.mimet.2021.106233.

Nakahara, H., T. Mori and N. Matsuzoe. 2021b. Screening of phenotypic conversion mutant strains of Ralstonia solanacearum for effective biological control of Verticillium wilt in eggplant. Crop Protection 142: 105530. DOI: 10.1016/j.cropro.2020.105530.

Nakahara, H., T. Mori, N. Sadakari, H. Matsusaki and N. Matsuzoe. 2016a. Biological control of the bacterial wilt of the tomato 'Micro-Tom' by phenotypic conversion mutants of Ralstonia solanacearum. Environ. Control Biol. 54: 139145.

Nakahara, H., T. Mori, N. Sadakari, H. Matsusaki and N. Matsuzoe. 2016b. Selection of effective non-pathogenic
Ralstonia solanacearum as biocontrol agents against bacterial wilt in eggplant. J. Plant Dis. Prot. 123: 119-124.

Nakaho, K., S. Takaya and Y. Sumida. 1996. Conditions that increase latent infection of grafted or non-grafted tomatoes with Pseudomonas solanacearum. Ann. Phytopathol. Soc. Jpn. 62: 234-239.

O'Brien, P. A. 2017. Biological control of plant diseases. Australasian Plant Pathol. 46: 293-304.

Ogawa, K., T. Mori, H. Matsusaki and N. Matsuzoe. 2011. Suppression of bacterial wilt in eggplant by non-pathogenic Ralstonia solanacearum. Hort. Res. (Japan) 10: 581-587 (In Japanese with English abstract).

Ozaki, K. and T. Kimura. 1992. Grouping of Pseudomonas solanacearum on the basis of pathogenicity to Solanum plants. Bull. Chugoku Natl. Agric. Exp. Stn. 10: 49-58 (In Japanese with English abstract).

Pegg, G. L. and B. L. Brady. 2002. Verticillium wilts. CABI, Wallingford, Oxon, U.K.

Saile, E., J. A. McGarvey, M. A. Schell and T. P. Denny. 1997. Role of extracellular polysaccharide and endoglucanase in root invasion and colonization of tomato plants by Ralstonia solanacearum. Phytopathology 87: 1264-1271.

Tjamos, S. E., E. Flemetakis, E. J. Paplomatas and P. Katinakis. 2005. Induction of resistance to Verticillium dahliae in Arabidopsis thaliana by the biocontrol agent K-165 and pathogenesis related proteins gene expression. Mol. PlantMicrobe Interact. 18: 555-561.

van Loon, L. C., W. S. Pierpoint, T. H. Boller and V. Conejero. 1994. Recommendations for naming plant pathogenesisrelated proteins. Plant Mol. Biol. Rep. 12: 245-264.

Vanitha, S. C. and S. Umesha. 2008. Variations in defense related enzyme activities in tomato during the infection with bacterial wilt pathogen. J. Plant Interact. 3: 245-253.

Vanitha, S. C. and S. Umesha. 2011. Pseudomonas fluorescens mediated systemic resistance in tomato is driven through an elevated synthesis of defense enzymes. Biol. Plant 55: 317 322.

Vanitha, S. C., S. R. Niranjana and S. Umesha. 2009. Role of phenylalanine ammonia lyase and polyphenol oxidase in host resistance to bacterial wilt of tomato. J. Phytopathol. 157: 552-557.

Verberne, C. M., J. Hoekstra, J. F. Bol and H. J. M. Linthorst. 2003. Signaling of systemic acquired resistance in tobacco depends on ethylene perception. Plant J. 35: 27-32.

Yamakawa, K. 1982. Use of rootstocks in Solanaceous fruitvegetable production in Japan. Jpn. Agr. Res. Q. 15: 175179.

Yoshida, T. 2007. Utilization of disease resistant rootstocks for soil-born disease in eggplant. Plant Protection 61: 671-675 (In Japanese). 